\title{
HEPATOLITIASIS: KASUS SERIAL DI RSUD DR. SOETOMO
}

\author{
Made Mahayasa ${ }^{1}$, Tommy Lesmana ${ }^{2}$ \\ ${ }^{1}$ Trainee Divisi Bedah Digestif, Departemen Ilmu Bedah, Fakultas Kedokteran Universitas Airlangga, RSUD \\ Dr. Soetomo, Surabaya, Indonesia. Korespondensi: mademahayasa@ gmail.com. \\ ${ }^{2}$ Divisi Bedah Digestif, Departemen Ilmu Bedah, Fakultas Kedokteran Universitas Airlangga, RSUD Dr. \\ Soetomo, Surabaya, Indonesia.
}

\begin{abstract}
ABSTRAK
Latar Belakang: hepatolitiasis adalah batu empedu pada saluran empedu liver dengan insidensi 20-30\% dari semua pasien yang menjalani operasi untuk penyakit batu empedu. Ada beberapa pilihan operasi hepatolitiasis, seperti hepatektomi, eksplorasi common bile duct (CBD), dan drainase saluran intrahepatik atau cholangioenterostomy (access loop procedures), dan teknik perkutaneus. Pada laporan kasus serial ini, akan dibahas aspek pemilihan operasi pada pasien dengan hepatolitiasis. Kasus: kasus pertama adalah laki-laki, 60 tahun, dirawat di Rumah Sakit Dr. Soetomo dengan nyeri abdomen kuadran kanan atas sejak 2 minggu. Diagnosis dengan USG (ultrasonografi) abdomen dan MRCP (magnetic resonance cholangiopancreatography) menunjukkan terdapat beberapa batu di IHBD (intra hepatic bile duct), CHD (common hepatic duct), CBD, GB (gall bladder), dan sistem bilier yang melebar. Pada pasien dilakukan tindakan kolesistektomi, eksplorasi duktus, dan by pass bilio-digestive Roux en Y (access loop procedures). Kasus kedua adalah perempuan, 45 tahun, dirawat di Rumah Sakit Dr. Soetomo dengan didiagnosis batu IHBD dan CBD. Penderita telah dilakukan kolesistektomi sejak 12 tahun yang lalu. Durante operasi ditemukan atrofi lobus kiri hati. Pada pasien, dilakukan operasi dengan eksplorasi duktus, by pass bilio-digestive Roux en Y (access loop procedures), dan hepatektomi lobus kiri. Simpulan: kasus hepatolitiasis jarang terjadi di Rumah Sakit Dr. Soetomo Surabaya. Diagnosis lengkap memerlukan kombinasi modalitas pencitraan. Pembedahan tetap menjadi pilihan utama pengobatan definitif. Menurut strategi terapeutik saat ini untuk hepatolitiasis, hepatektomi tampaknya merupakan pengobatan yang paling efektif untuk pasien dengan hepatolitiasis kiri yang terisolasi jika prosedur pembedahan lain tidak dapat mengatasi semua lesi terkait. Perawatan yang baik dapat memberikan luaran yang baik.
\end{abstract}

Kata kunci: hepatolitiasis, by pass bilio-digestive, hepatektomi.

\section{HEPATOLITHIASIS: SERIAL CASES IN DR. SOETOMO GENERAL HOSPITAL}

\author{
Made Mahayasa ${ }^{1}$, Tommy Lesmana ${ }^{2}$ \\ ${ }^{1}$ Trainee of Division of Digestive Surgery, Department of Surgery, Faculty of Medicine Airlangga University, \\ Dr. Soetomo Hospital, Surabaya, Indonesia. Correspondence: mademahayasa @ gmail.com. \\ ${ }^{2}$ Division of Digestive Surgery, Department of Surgery, Faculty of Medicine Airlangga University, Dr. Soetomo \\ Hospital, Surabaya, Indonesia.
}

\begin{abstract}
Background: hepatolithiasis is the presence of gallstones in the biliary duct of the liver with 20$30 \%$ cases reported in all patients underwent surgery for gallstone. There are several surgical options for hepatolithiasis, such as hepatectomy, common bile duct (CBD) exploration, and intrahepatic duct drainage or cholangioenterostomy (access loop procedures), and percutaneous technique. To discuss these options are our aim in this case series. Case: the first case was a 60-year-old male who admitted to Dr. Soetomo Hospital with upper right quadrant abdominal pain within the past 2 . The diagnosis by
\end{abstract}


USG (ultrasonography) of the abdomen and MRCP (magnetic resonance cholangiopancreatography) confirmed multiple stone of IHBD (intra hepatic bile duct), CHD (common hepatic duct), CBD, GB (gall bladder), and widening biliary system. This patient underwent cholecystectomy, ductus exploration, and by pass bilio-digestive Roux en Y (access loop procedures). The second case was a 45-year-old woman who admitted to Dr. Soetomo Hospitals with multiple stones of IHBD and CBD. She underwent cholecystectomy 12 years before admission. During operation, we found left lobe atrophy of liver. Then patient was operated with ductus exploration, by pass bilio-digestive Roux en Y, and left lobe hepatectomy. Conclusion: hepatolithiasis was uncommon in Surabaya. Complete diagnosis requires a combination of imaging modalities. Surgery remains the mainstay of definitive treatment. According to the current therapeutic strategy for hepatolithiasis, hepatectomy was the most effective treatment for selected patients with isolated left hepatolithiasis if other surgical procedures fail to remove all the related lesions. With adequate treatment, good outcome is possible.

Keywords: hepatolithiasis, by pass bilio-digestive, hepatectomy.

\section{PENDAHULUAN}

Hepatolitiasis didefinisikan sebagai batu empedu yang terletak pada semua saluran empedu dari perifer sampai pertemuan duktus hepatikus kanan dan kiri, terlepas dari adanya batu empedu di bagian lain dari saluran empedu, seperti saluran empedu ekstrahepatik dan atau kandung empedu. Batu empedu yang ditemukan di atas pertemuan ini dianggap batu empedu intrahepatik, terlepas apakah pertemuan ini terletak intrahepatik atau ekstrahepatik. ${ }^{1,2}$

Penyakit ini pertama kali dipublikasikan oleh Vachell \& Stevens tahun 1906. Hepatolitiasis memiliki nama lain diantaranya Hong Kong disease, Biliary Obstruction Syndrome of the Chinese, atau Oriental Cholangitis, hal ini dikarenakan hepatolitiasis lebih sering terjadi pada negara Asia. ${ }^{1}$ Angka kejadian hepatolitiasis dilaporkan terjadi pada 20$30 \%$ pasien yang menjalani operasi kandung empedu. ${ }^{1,3}$ Angka kejadian hepatolitiasis relatif rendah di Eropa maupun Amerika Utara yaitu di bawah $1 \% .^{3-5}$

Lokasi hepatolitiasis paling sering terjadi pada duktus hepatikus kiri. ${ }^{2}$ Hal ini berdasarkan posisi anatomi, pertemuan duktus hepatikus kanan dan kiri membentuk sudut yang tajam, dimana duktus hepatikus kiri berjalan lebih horizontal dibandingkan duktus hepatikus kanan. ${ }^{2}$ Pada keadaan yang sangat jarang, beberapa cabang dari duktus hepatikus kanan berjalan menuju ke duktus hepatikus kiri. Pada hepatolitiasis dapat disertai dengan pelebaran saluran empedu intra maupun ekstrahepatik dan atau striktur saluran empedu. ${ }^{6,7}$

Etiologi hepatolitiasis di Negara Barat pada umumnya terjadi secara sekunder, yang berasal dari batu kandung empedu atau dapat juga sebagai batu primer karena terdapatnya striktur saluran empedu, sklerosing kolangitis, kista duktus koledokus atau tumor ganas saluran empedu. ${ }^{8}$ Di Asia, sering disebabkan oleh kolangitis piogenik berulang dan juga berkaitan dengan infeksi parasit (golongan cacing Clonorchis sinensis dan Ascaris lumbricoides) maupun diet. ${ }^{89}$ Keradangan saluran empedu yang berulang akan menimbulkan terbentuknya striktur dari saluran empedu yang dapat menyebabkan stasis dari cairan empedu. Keradangan ini juga menyebabkan dinding saluran 
empedu menebal dan membentuk jaringan fibrotik. $^{2}$

Gejala yang sering timbul diantaranya nyeri perut kanan atas berulang, demam, ikterus berulang, peningkatan tes fungsi hati dengan peningkatan alkali fosfatase, dan dapat disertai abses hepar, atrofi lobus hepatik, kolangitis, dan kolangiokarsinoma. ${ }^{8,10}$ Dari pemeriksaan laboratorium didapatkan peningkatan kadar sel darah putih, peningkatan fungsi liver dengan disertai peningkatan alkali fosfatase, kadar bilirubin yang abnormal. ${ }^{8,10}$ Pada pemeriksaan radiologis, yang dapat membantu menegakkan diagnosis hepatolitiasis, diantaranya USG abdomen, CT-Scan abdomen dan MRI / MRCP (magnetic resonance imaging / magnetic resonance

cholangiopancreatography). ${ }^{10}$

\section{KASUS SERIAL}

\section{Kasus 1}

Seorang laki laki, petani, usia 60 tahun, datang ke klinik bedah dengan keluhan nyeri perut kanan bagian atas, sejak 15 hari yang lalu. Nyeri dirasakan timbul mendadak, seperti ditusuk-tusuk, hilang timbul, sampai tembus ke punggung. Pasien juga mengeluhkan mata dan telapak tangannya menguning. Terdapat riwayat kuning sebelumnya tapi menghilang sendiri. Warna air kencing pasien seperti teh sejak 15 hari yang lalu, tanpa nyeri saat kencing maupun anyang-anyangan. Buang air besar pasien lancar seperti biasa, tetapi warnanya pucat. Tidak didapatkan keluhan panas badan maupun menggigil. Pasien juga merasa mual tapi tidak sampai muntah, nafsu makan dirasakan berkurang, dan berat badan semakin menurun. Tidak didapatkan riwayat operasi. Tidak ada pula keluarga yang mempunyai keluhan seperti pasien.
Pemeriksaan fisik pasien menunjukkan kondisi umum pasien baik, dengan tandatanda vital dalam batas normal, tekanan darah 120/80 mmHg, nadi $88 \mathrm{kali} / \mathrm{menit}$ reguler, frekuensi nafas $20 \mathrm{kali} / \mathrm{menit}$, dan temperatur aksiler $36,5^{\circ} \mathrm{C}$. Didapatkan kedua sklera ikterik. Tidak didapatkan kelainan pada pemeriksaan thoraks. Pada pemeriksaan abdomen didapatkan abdomen datar, bising usus yang normal, palpasi abdomen menunjukkan adanya nyeri tekan pada pada kuadran kanan atas tanpa tanda Murphy. Didapatkan pembesaran hepar 3 jari dibawah arkus kosta, permukaan rata, ujung tajam, nyeri tekan. Pada ekstremitas didapatkan telapak tangan berwarna kekuningan. Pemeriksaan colok dubur dalam batas normal.

Dari pemeriksaan laboratorium didapatkan pemeriksaan darah lengkap dalam batas normal (leukosit 6,25 $10^{3} / \mu 1$,

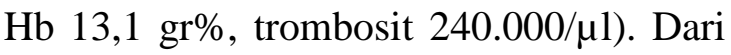
pemeriksaan fungsi hati didapatkan peningkatan fungsi liver (SGOT $79 \mathrm{U} / \mathrm{L}$, SGPT $50 \mathrm{U} / \mathrm{L})$, peningkatan alkali fosfatase (ALP $652 \mathrm{U} / \mathrm{L}$ ), dan peningkatan kadar bilirubin total maupun direk (bilirubin total $10,78 \mathrm{mg} / \mathrm{dl}$, bilirubin direk $8,0 \mathrm{mg} / \mathrm{dl})$ sedangkan albumin normal $(3,3$ $\mathrm{g} / \mathrm{dl}$ ). Pada pemeriksaan laboratorium didapatkan kadar gamma GT yang meningkat, dengan nilai $837 \mathrm{U} / \mathrm{L}$. Hasil dari pemeriksaan faal hemostasis didapatkan pemanjangan jalur intrinsik (47,9 detik, kontrol 30,5 detik). Didapatkan profil lipid abnormal, kadar HDL rendah $(20 \mathrm{mg} / \mathrm{dl})$, kolesterol LDL sedikit meningkat (132 mg/dl), serta kadar trigliserida yang meningkat (229 mg/dl). Sedangkan pemeriksaan fungsi ginjal dan serum elektrolit dalam batas normal.

Pada pemeriksaan USG abdomen didapatkan pembesaran hepar dengan intensitas hypoechoic, dan sudut yang 
tumpul, permukaan kasar, vena hepatika sempit, porta yang tidak melebar, dengan sebagian saluran hepatobilier yang melebar. Pada kandung empedu didapatkan kandung empedu yang besar dengan gambaran massa hiperekoik pada dasar kantong empedu dengan kesan melekat pada dinding. Common bile duct (CBD) melebar yang kemudian berhenti di sekitar pankreas. Tidak didapatkan kelainan pada pankreas, lien, maupun pada kedua ginjal (gambar 1). Dari pemeriksaan USG tersebut disimpulkan terdapat hepatosplenomegali, curiga suatu hepatitis kronis, serta hydrops gall bladder, dan curiga polip gall bladder.

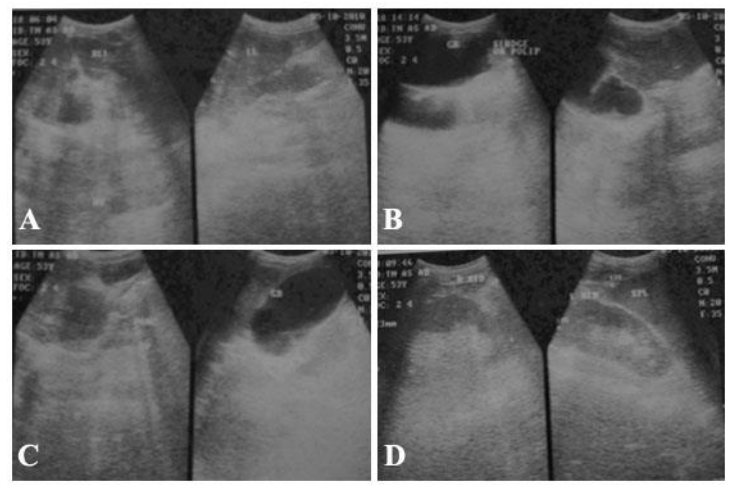

Gambar 1. USG abdomen; A. Hepatomegali disertai pelebaran saluran empedu intrahepatik lobus kanan dan kiri; B-C. Kandung empedu melebar disertai gambaran massa hiperekoik pada dasar kandung empedu; D. Splenomegali.

Untuk mengetahui kondisi saluran empedu lebih baik serta posisi batu maka pasien dilakukan pemeriksaan MRI abdomen maupun MRCP. Dari pemeriksaan ini didapatkan hepar besar dan bentuk normal. Parenkim homogen dengan intensitas normal. Tidak didapatkan tumor maupun kiste. Tampak batu multipel pada IHBD (intra hepatic bile duct) yang menyebabkan dilatasi IHBD cabang kanan maupun kiri. Pada pemeriksaan MRCP didapatkan GB membesar, tampak batu multipel didalamnya dan pada cystic duct, dinding masih normal. Duktus koledokus melebar dengan batu didalamnya (gambar 2). Duktus hepatikus normal dengan batu didalamnya, sedangkan duktus pankreatikus normal. Pankreas normal, tak tampak tumor. Terdapat kista multipel pada korteks kedua ginjal, tidak ada hidronefrosis maupun batu atau nodul. Lien membesar dan tidak terdapat pembesaran kelenjar para aorta. Dari pemeriksaan MRI abdomen dan MRCP disimpulkan terdapat batu multipel di IHBD, CHB (common hepatic duct), CBD, GB, dan kista duktus yang disertai pelebaran sistem bilier (gambar 2). Didapatkan pula kista ginjal multipel pada kedua ginjal, serta splenomegali.
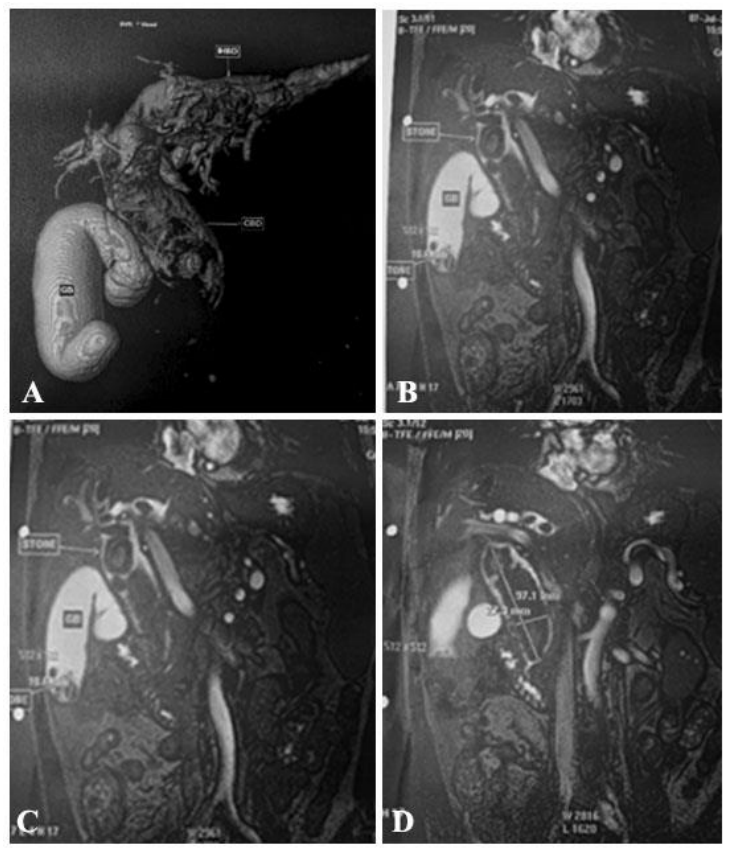

Gambar 2. A. GB, CBD, dan IHBD melebar; B. Gambaran batu empedu pada GB dan duktus koledokus; C. CBD melebar dengan diameter $2 \mathrm{x}$ $10 \mathrm{~cm}$; D. Gambaran pelebaran IHBD dan batu empedu didalamnya

Berdasarkan anamnesis, pemeriksaan fisik, pemeriksaan penunjang, pasien didiagnosis dengan ikterus obstruktif, Batu $\mathrm{GB}, \mathrm{CBD}$ stone dengan diagnosis banding 
choledococyst dengan hepatolitiasis.

Berdasarkan data-data tersebut diatas pasien diputuskan untuk dilakukan operasi. Tanggal 13 Juli 2010 pasien menjalani operasi. Pada pasien ini dilakukan tindakan berupa eksplorasi duktus, kolesistektomi dan by pass bilio-digestive Roux en Y. Pada eksplorasi, didapatkan GB melebar dengan dinding yang menebal. Didapatkan pula CBD yang menebal, Hartmann pouch yang dilatasi dan teraba batu di GB maupun pada CBD (gambar 3). Kemudian dilakukan kolesistektomi dan eksplorasi CBD, didapatkan batu ukuran $12 \times 7 \mathrm{~cm}$ dan batu multipel lainnya dengan ukuran diameter bervariasi antara 0,5-2 cm. Dilakukan ekstraksi batu, dan dilanjutkan dengan eksplorasi duktus hepatikus kanan dan kiri. Pada eksplorasi duktus tersebut didapatkan batu empedu multipel dengan ukuran $\pm 1 \mathrm{~cm}$, dilakukan pembilasan pada duktus dengan menggunakan cairan $\mathrm{NaCl}$ 0,9 \% hingga jernih (tidak keluar batu). Kemudian CBD dijahit dengan menggunakan benang vicryl. Setelah dilakukan evakuasi batu empedu maka operasi dilanjutkan dengan dilakukan by pass CBD dengan jejunum $30 \mathrm{~cm}$ dari ligamentum Treitz (choledocojejunostomy side to side anastomosis). Stump jejunum dibuat sebagai jejunal pouch yang diletakkan diatas fasia rektus anterior subkutis, sedangkan jejeunum distal dilakukan jejunojejenostomi end to side.

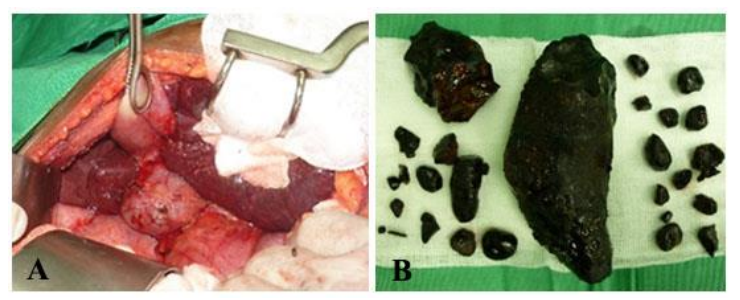

Gambar 3. A. Gambaran durante operasi; B. Batu empedu yang didapatkan durante operasi.
Batu empedu yang didapatkan saat operasi dilakukan analisis batu (gambar 3). Dari analisis batu tersebut didapatkan batu dengan ukuran terbesar $8 \times 3 \times 4 \mathrm{~cm}$, warna hitam, keras, rapuh, dan reaksi asam. Hasil analisis didapatkan kandungan kolesterol dan asam urat pada batu empedu tersebut.

\section{Kasus 2}

Penderita perempuan, 45 tahun, dengan keluhan nyeri perut kanan atas sejak pagi sebelum ke rumah sakit, nyeri dirasakan hilang timbul, disertai demam, mata sedikit kuning dan BAK seperti teh. Penderita pernah operasi pengangkatan kandung empedu 12 tahun yang lalu.

Pada pemeriksaan fisik didapatkan tekanan darah 120/80 $\mathrm{mmHg}$, nadi 80 kali/menit, laju respirasi $18 \mathrm{kali} / \mathrm{menit}$, temperatur $38,2{ }^{0} \mathrm{C}$. Mata menunjukkan sedikit ikterus, pada abdomen didapatkan jaringan parut bekas operasi kolesistektomi, dan Murphys sign. Hasil pemeriksaan laboratorium menunjukkan peningkatan fungsi hati (SGOT $68 \mathrm{U} / \mathrm{L}$ dan SGPT $56 \mathrm{U} / \mathrm{L}$ ), bilirubin direk dan indirek dalam batas normal.

Hasil pemeriksaan USG menunjukkan batu kecil multipel di saluran bilier cabang kanan dan kiri disertai tanda kolangitis. Duktus koledokus melebar ringan (gambar 4). Pemeriksaan MRCP memberikan gambaran adanya pelebaran serta batu multipel pada duktus hepatikus kanan dan kiri. Tidak tampak gambaran kandung empedu (paska kolesistektomi) (gambar 5).

Dari anamnesis, pemeriksaan fisik, dan penunjang, maka penderita ini didiagnosis dengan batu multipel duktus hepatikus kanan dan kiri serta batu CBD. Penderita dilakukan operasi pada tanggal 26 April 2010. 


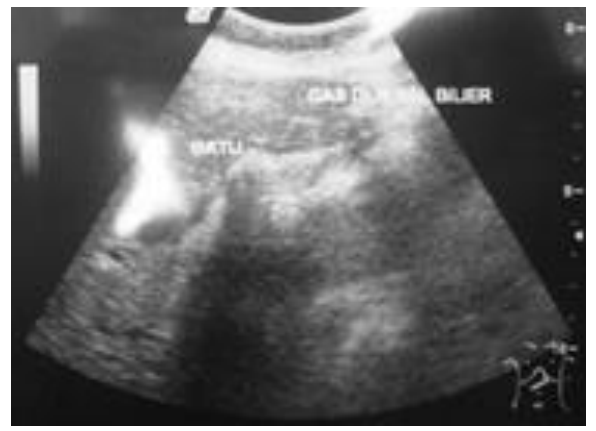

Gambar 4. Tampak gambaran batu multipel di duktus hepatikus kanan dan kiri disertai adanya gambaran gas (kolangitis).

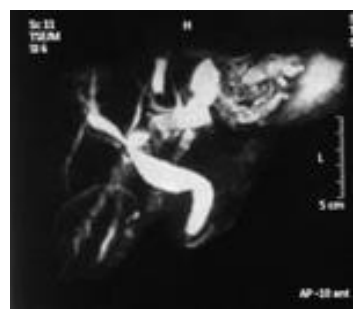

Gambar 5. Hasil

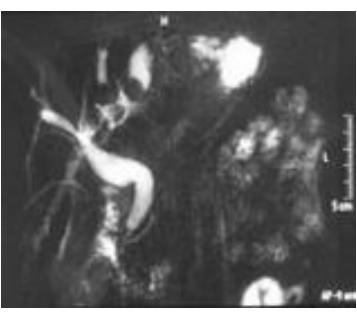
pemeriksaan MRCP menunjukkan adanya gambaran batu multipel pada duktus hepatikus kanan dan kiri disertai pelebaran duktus hepatikus, batu pada distal CBD. Gambaran gall bladder tidak tampak (pasca kolesistektomi).

Durante operasi didapatkan pelebaran duktus koledokus, teraba batu pada distal CBD, teraba batu di duktus hepatikus kanan dan kiri, atropi lobus kiri hepar. Dilakukan koledokolitotomi dan hepatikolitotomi (gambar 6), selanjutnya dilakukan hepatektomi lobus kiri hepar (gambar 7).

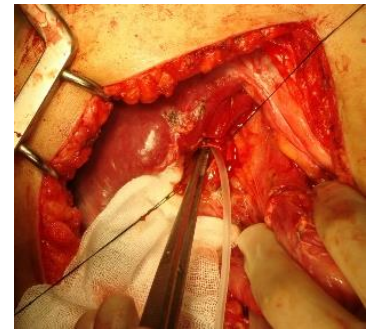

Gambar 6. Durante

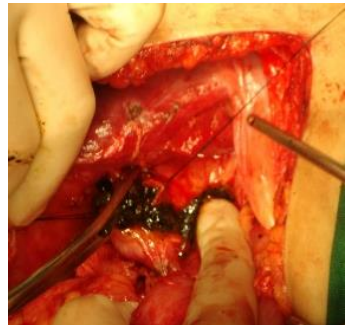

operasi dilakukan koledokolitotomi dan hepatikolitotomi.

Setelah itu dilakukan tindakan by pass koledokojejunostomi, jejunojejunostomi Roux $\mathrm{n}$ Y, sementara stump proksimal jejunum dibuat jejunal pouch sebagai access loop procedure.
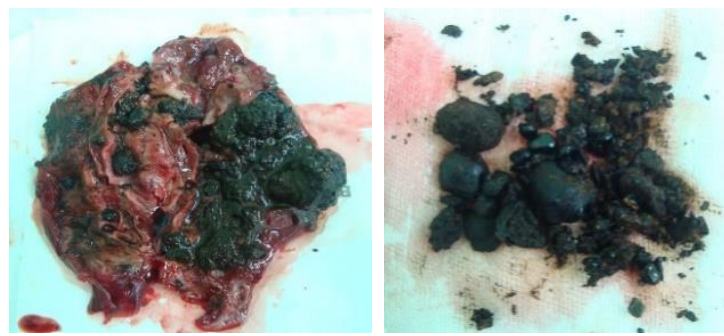

Gambar 7. Hepatektomi lobus kiri hepar. Didapatkan batu multipel yang memenuhi hampir seluruh saluran bilier.

\section{DISKUSI}

Hepatolitiasis adalah suatu penyakit dimana terdapat batu/kalkulus yang terletak diproksimal dari pertemuan antara duktus hepatikus kanan dan kiri, dan dapat juga ditemui di percabangan duktus hepatikus. Hepatolitiasis dapat juga bersamaan dengan koledokolitiasis atau kolesistolitiasis. $^{2}$

Angka kejadian hepatolitiasis dilaporkan terjadi pada $20-30 \%$ pasien yang menjalani operasi kandung empedu. ${ }^{1-}$ ${ }^{3}$ Sedangkan angka kejadian hepatolitiasis relatif rendah di Eropa maupun Amerika Utara yaitu di bawah $1 \% .^{3-5}$ Tidak ada perbedaan angka insiden antara laki-laki dan perempuan. Hepatolitiasis biasanya muncul antara dekade ke-3 sampai ke-7, terutama terjadi pada masyarakat ekonomi menengah ke bawah. ${ }^{12}$

Pada hepatolitiasis dikenal klasifikasi Nakayama (1982), yang membagi berdasarkan letak batu empedu, adanya striktur dan dilatasi saluran empedu. Klasifikasi ini kemudian diperbaharui oleh The Japan Research Group for the Study of Hepatolithiasis yang membagi pasienpasien dengan hepatolitiasis menjadi 2 kelompok besar yaitu pasien dengan batu hanya di duktus intrahepatikus (tipe I) dan pasien-pasien dengan batu pada duktus 
intrahepatikus dan ekstrahepatikus (tipe IE). ${ }^{13}$ Selanjutnya pasien dikelompokkan lagi berdasarkan lokasi batu terhadap hepar, yaitu lobus kanan (tipe R), lobus kiri (tipe L), lobus kanan dan kiri (tipe LR), dan lobus kaudatus (tipe C) (gambar 8). 2,14

Pada kasus pertama ini didapatkan batu multipel pada IHBD cabang kanan maupun kiri sehingga termasuk tipe I dan LR. Sedangkan pada kasus kedua didapatkan batu pada IHBD cabang kanan dan kiri dengan predominan ke kiri juga termasuk tipe I dan LR.

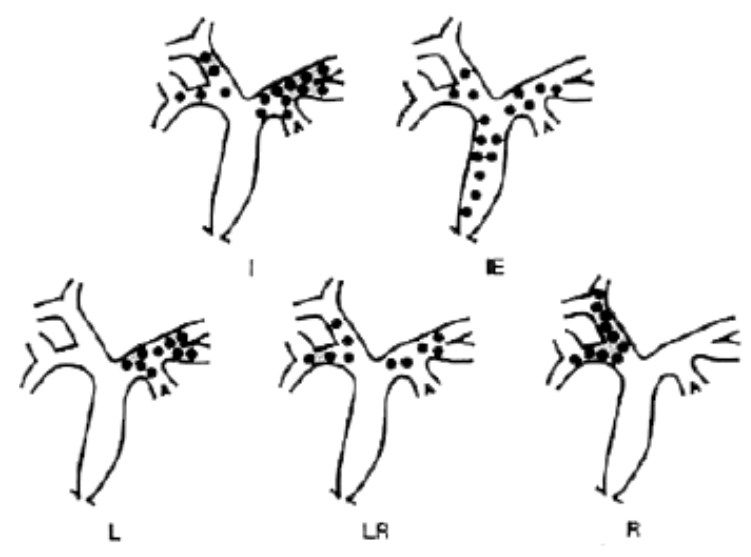

Gambar 8. Lokasi batu empedu berdasarkan klasifikasi Nakayama. $^{2}$

Klasifikasi selanjutnya didasarkan atas adanya striktur saluran empedu yang dibagi menjadi 3, yaitu S0: tidak didapatkan striktur, S1: striktur ringan (diameter $>2 \mathrm{~mm}$ ), dan S2: striktur berat (diameter $<2 \mathrm{~mm})^{2}$

Pada kasus pertama tidak didapatkan gambaran striktur pada saluran empedu. Sedangkan pada kasus kedua didapatkan striktur berat pada duktus hepatikus kiri.

Komponen klasifikasi Nakayama yang ketiga adalah adanya dilatasi dari saluran empedu, yaitu D0: tidak adanya dilatasi, D1: dilatasi ringan, dan D2: dilatasi berat. Dilatasi berat untuk duktus extrahepatik memiliki ukuran $\geq 20 \mathrm{~mm}$, sedangkan ukuran untuk duktus intrahepatik sebesar $\geq$ $10 \mathrm{~mm} .^{2}$ Pada kasus pertama didapatkan dilatasi berat (D2) dari saluran empedu baik IHBD kanan kiri, maupun pelebaran duktus koledokus $(2,73 \mathrm{~cm})$. Sedangkan pada kasus ke dua juga didapatkan dilatasi IHBD kiri.

Terdapat perbedaan etiologi di negara Barat dan Asia. Di negara Barat pada umumnya hepatolitiasis terjadi sekunder oleh karena batu berasal dari kandung empedu atau primer karena adanya striktur saluran empedu, sclerosing cholangitis, choledocal cyst atau tumor ganas saluran empedu. ${ }^{8}$ Sedangkan di Asia, hepatolitiasis paling sering disebabkan oleh kolangitis piogenik berulang dan juga berkaitan dengan infeksi parasit (golongan cacing Clonorchis sinensis dan Ascaris lumbricoides) maupun diet. ${ }^{8,9}$ Pada kasus pertama didapatkan pasien bekerja sebagai petani, yang memiliki kemungkinan terinfeksi dengan parasit, akan tetapi belum dapat dibuktikan dengan pasti. Pasien juga pernah mengeluh kuning sebelumnya, yang bisa merupakan kemungkinan adanya batu atau kelainan pada empedu/saluran empedu atau infeksi pada hepar. Sedangkan pada kasus kedua kemungkinan penyebabnya adalah akibat kolangitis piogenik berulang (terdapat gambaran gas pada saluran bilier).

Infeksi bakteri juga berpengaruh terhadap terjadinya hepatolitiasis. Normalnya cairan empedu manusia steril. Insiden terdapatnya bakteri pada cairan empedu hampir $100 \%$ ditemui pada pasien dengan hepatolitiasis. ${ }^{11}$ Bakteri tersering antara lain Klebsiella sp, E. Coli, Pseudomonas sp. ${ }^{11}$ Kuman ini dapat masuk ke dalam saluran bilier melalui luka/ kerusakan yang sebabkan oleh infeksi parasit. Infeksi bakteri pada umunnya polimikrobial, dan umumnya 
bakteri penyebab mempunyai aktifitas untuk memproduksi B-glukoronidase. ${ }^{2} \mathrm{~B}$ glukoronidase ini bertanggung jawab dalam mengkatalase hidrolisis bilirubin terkonjugasi menjadi bilirubin tidak terkonjugasi. $^{2}$ Bila aktifitas ini terjadi, maka akan terjadi peningkatan bilirubin tidak terkonjugasi, yang bila bereaksi dengan kalsium bilirubinat akan membentuk batu kalsium bilirubinat (batu pigmen) yang merupakan batu penyebab tersering pada hepatolitiasis $(80 \%)^{2}$. Sedangkan batu kolesterol maupun batu campuran, kejadian semakin meningkat (10 \%) akibat pola konsumsi makanan ala barat yang dikonsumsi oleh orang Asia. ${ }^{2}$ Pada kasus ini berdasarkan analisis batu, didapatkan batu berwarna hitam, keras, rapuh, bereaksi asam, dengan kandungan kolesterol dan asam urat.

Keradangan saluran empedu yang berulang dapat menyebabkan terjadinya hepatolitiasis. Kolangitis yang berulang akan menimbulkan terbentuknya striktur dari saluran empedu yang dapat menyebabkan stasis dari cairan empedu. ${ }^{2}$ Keradangan ini pun menyebabkan dinding saluran empedu menebal dan membentuk jaringan fibrotik. $^{2}$

Seratus dua puluh dua pasien yang menjalani pemeriksaan CT dan CTKolangiografi ditemukan memiliki hepatolitiasis. ${ }^{12}$ Empat belas diantaranya menjadi simptomatik dalam jangka 3-4 tahun setelah terdiagnosa. Gejala yang sering timbul diantaranya nyeri perut kanan atas berulang, demam, ikterus berulang, peningkatan LFT dengan peningkatan alkali fosfatase, dan dapat disertai abses hepar, atrofi lobus hepatik, kolangitis dan kolangiokarsinoma., ${ }^{4,8,12}$ Penelitian 54 pasien di RS Johns Hopkins 3 gejala tersering adalah kolangitis $(67 \%)$, nyeri perut $(63 \%)$, dan ikterus $(39 \%))^{4,8}$
Pada kasus pertama didapatkan keluhan utama nyeri perut kanan atas, hepar membesar, tidak didapatkan tanda-tanda kolangitis, murphy's sign negatif. Sedangkan pada pasien kedua didapatkan dengan nyeri perut kanan atas, ikterus, demam, dan disertai tanda-tanda kolangitis.

Dari pemeriksaan laboratorium didapatkan peningkatan kadar sel darah putih, fungsi liver dengan disertai peningkatan alkali fosfatase, kadar bilirubin yang abnormal. ${ }^{4,8}$ Pada kasus ini dari pemeriksaan laboratorium didapatkan peningkatan SGOT dan SGPT, yang menandakan terdapat proses keradangan pada hepar. Didapatkan pula peningkatan bilirubin total maupun bilirubin direk, yang menandakan terdapatkan obstruksi saluran empedu. Kadar alkali fosfatase dan gamma $G T$ juga meningkat yang berarti terdapat kelainan pada saluran empedu. Pada pasien didapatkan kadar profil lipid yang abnormal, yang menjadi salah satu faktor yang dapat menyebabkan terbentuknya batu empedu.

Pada pemeriksaan radiologis, yang dapat membantu menegakkan diagnosis hepatolitiasis, diantaranya USG abdomen dan MRI / MRCP. Pada pemeriksaan USG abdomen, pada hepatolitiasis dapat ditemukan pelebaran dari saluran empedu intrahepatik maupun ekstrahepatik dan juga dapat ditemukan adanya batu dalam saluran empedu baik intra maupun ekstra hepatik (85-90\%). Pada kasus ini pada USG abdomen didapatkan hepatomegali dengan sebagian saluran hepatobilier yang melebar. Didapatkan pula GB, CBD yang melebar. Modalitas radiologis yang lain, yaitu MRI (MRCP, ERCP, dan PTC) dapat mengetahui mapping dari saluran empedu dengan lebih baik, sehingga dapat mengetahui saluran empedu sampai 
percabangannnya, dan kelainan yang mungkin terjadi. Pada kasus ini didapatkan batu multipel di IHBD, CHB (common hepatic duct), $\mathrm{CBD}, \mathrm{GB}$, dan kista duktus yang disertai pelebaran sistem bilier.

Tujuan terapi pada hepatolitiasis ada dua, yaitu usaha untuk mencegah kerusakan hepar lebih lanjut, dengan cara mengambil batu lebih cepat dan mengeliminasi bile stasis, dengan cara menghilangkan batu, menghilangkan striktur saluran empedu, menjamin drainase cairan empedu dengan baik (untuk meminimalkan infeksi bakteri), reseksi sumber penyebab infeksi berulang/bile stasis, reseksi kolangiokarsinoma, menghilangkan liver atrofi, menghilangkan abses hepatik. ${ }^{4}$ Selain itu, batu residual sebaiknya dapat secara spontan bergerak masuk kedalam saluran cerna. ${ }^{4}$

Pilihan operasi pada pasien dengan hepatolitiasis sangat bervasiasi, hal ini tergantung dari kondisi dan status masingmasing pasien. Secara garis besar ada tiga pilihan operasi untuk terapi hepatolitiasis, yaitu hepatektomi, eksplorasi CBD dan duktus intrahepatik dengan drainase bilier atau kolangioenterostomi (access loop procedures), dan yang terakhir dengan teknik perkutaneus. ${ }^{8,10}$ Selain itu pada kasus hepatolitiasis primer, ESWL merupakan pilihan pertama pada batu kolesterol, hepatektomi sebaiknya menjadi pilihan pertama pada hepatolitiasis tipe $\mathrm{L}$ dan $\mathrm{R}$ dengan batu kalsium, dan Percutaneous Transhepatic Cholangioscopic Lithotripsy (PTCSL) sebaiknya dikerjakan pada hepatolitiasis tipe LR dan batu empedu berulang ${ }^{10}$ (gambar 5). Pada kasus ini diputuskan untuk dilakukan operasi eksplorasi duktus dan dilanjutkan dengan koledokojejunostomi side to side (anastomosis biliodigestif Roux en Y) unjuk menjamin drainase bilier dengan baik. $^{10}$

Pada kasus hepatolitiasis sekunder (disertai koledokolitiasis), jika tidak didapatkan atrofi hepar dan tidak didapatkan stenosis duktus intrahepatik, maka kolangioenterostomi, drainase dengan T-tube, atau spingterostomi endoskopik sebaiknya dikerjakan sebagai terapi hepatolitiasis. ${ }^{10}$

Untuk menghilangkan batu empedu intrahepatik dapat dilakukan melalui koledoskopik perkutaneus transhepatik. Dari studi retrospektif, didapatkan 79 pasien dengan hepatolitiasis yang telah dilakukan tindakan diatas, didapatkan 76,8 $\%$ pasien sukses. ${ }^{13}$ Pengambilan batu empedu pada saluran hepatika kanan lebih sulit dari pada sisi kiri. Didapatkan komplikasi berupa kolangitis berulang dari 1/3 pasien dalam kurun waktu 3-5 tahun setelah operasi. ${ }^{13}$

Extracorporeal Shock Wave Lithotripsy (ESWL) dapat dimanfaatkan sebagai salah satu alternatif terapi pada hepatolitiasis. ${ }^{10,15}$ Akan tetapi terapi ini terbentur dengan cara untuk mengekstraksi batu yang sudah di "pecah", apalagi terdapat striktur pada saluran empedu. Dilaporkan ESWL dapat menghilangkan $95 \%$ batu pada hepatolitiais bila dikombinasikan dengan ERCP dan electrohydraulic lithotripsy, serta tidak didapatkannya kelainan pada saluran empedu. ${ }^{10,15}$

Pengambilan batu empedu dengan menggunakan alat endoskopik dapat dilakukan secara retrograde. Keuntungan teknik ini dapat menjangkau saluran empedu ekstra maupun intra hepatik, sehingga dapat mengambil batu pada hampir semua saluran empedu. ${ }^{2}$ Akan 
tetapi teknik ini sangat sulit dengan angka kegagalan yang relatif tinggi. ${ }^{2}$

Selain menghilangkan batu empedu, yang perlu diperhatikan selanjutnya adalah bagaimana agar drainase cairan bilier lancar, sehingga tidak menimbulkan bile stasis yang dapat mencegah timbulnya batu empedu berulang. ${ }^{2}$ Pada pasien dengan hepatolitiasis yang disebabkan oleh karena striktur saluran empedu, maka untuk mencegah kekambuhan dan komplikasi yang ditimbulkan oleh striktur saluran empedu, maka dapat dilakukan pemasangan metalik stent pada saluran empedu. ${ }^{16}$ Dari hasil studi, tidak didapatkan striktur saluran empedu berulang atau terbentuknya batu baru pada 6 pasien yang terpasang stent selama periode observasi 64 bulan. Sehingga stent metalik merupakan salah satu alternatif terapi pasien hepatolitiasis yang disertai striktur saluran empedu. ${ }^{16}$

Untuk menjamin drainase saluran empedu pada pasien hepatolitiasis, dapat juga menggunakan choledochostomy approach. ${ }^{2}$ Pada teknik ini sebelumnya pasien sudah dilakukan explorasi CBD dan disertai pemasangan $T$-tube. ${ }^{2}$ Pada cara ini dilakukan insersi balon / basket kateter, kemudian dilakukan koledokofiberskopi. Aprroach ini memiliki kekurangan, karena cara ini hanya terbatas pada saluran empedu intrahepatik sebelah kiri saja, karena terdapat kesulitan untuk menjangkau saluran empedu intrahepatik kanan karena membentuk sudut yang menyulitkan untuk insersi kateter. ${ }^{2}$

Koledokojejunostomi sering dilakukan untuk menangani pasien dengan hepatolitiasis. ${ }^{10,17}$ Koledokojejunostomi diindikasikan bila terdapat konstriksi saluran empedu dibawah percabangan duktus hepatikus kanan dan kiri. Tindakan ini tidak boleh dilakukan bila didapatkan adanya konstriksi saluran empedu intrahepatik. $^{10}$ Bila saluran empedu intrahepatik konstriksi dapat memicu timbulnya komplikasi pasca operasi berupa kolangitis intrahepatik, sehingga memerlukan perawatan lebih ketat. $^{17}$ Selain itu koledokojejunostomi diindikasikan bila batu intrahepatik terletak di kedua lobus dan untuk mengevakuasi batu residual setelah dilakukan litotripsi. ${ }^{10,17}$ Untuk menjamin eliminasi batu secara alami, pada umunya dilakukan pemasangan $T$-tube di CBD atau retrograde transhepatic billiary drainage tube yang diletakkan di saluran empedu dimana batu empedu residual ditemukan. ${ }^{10}$ Pada kasus yang pertama dilakukan koledokojejunostomi setelah dilakukan eksplorasi duktus, serta ekstraksi batu empedu karena terdapat batu pada saluran empedu intrahepatik kedua lobus. Untuk akses evakuasi batu residual atau residif dilakukan "access loop procedure" dari jejunal pouch yang ditempatkan dibawah kulit.

Hepatektomi merupakan alternatif pilihan terapi pada hepatolitiasis. ${ }^{10,18,19}$ Keuntungan terbesar terkait dengan melakukan hepatektomi pada hepatolitiasis adalah bahwa semua batu hati dapat dihilangkan bersama dengan patologi saluran empedu (termasuk saluran-saluran empedu carcinomatous), sehingga mengurangi risiko batu intrahepatik berulang. Hepatektomi paling sering diindikasikan untuk pengobatan hepatolitiasis tipe L, dan reseksi segmen lateral atau reseksi lobus kiri dilakukan untuk menghilangkan batu empedu intrahepatik dan saluran yang patologis. Dewasa ini insiden hepatolitiasis tipe I dan tipe L meningkat di Jepang, dan hepatektomi kini mengisi lebih dari 
setengah dari perawatan bedah untuk kasus ini.

Hepatektomi diindikasikan bila, hepatolitiasis terletak hanya pada satu lobus hepar, saluran empedu intrahepatik yang mengandung batu mengalami konstriksi/dilatasi, disertai dengan intrahepatic bile duct carcinoma, atau hepatolitiasis yang disertai abses atau atrofi hepar. ${ }^{10,18,19}$ Hepatektomi biasanya dikerjakan pada hepatolitiasis pada lobus kiri, jarang pada hepatolitiasis lobus kanan. Pada kasus ke-2 memenuhi indikasi untuk dilakukan hepatektomi yaitu batu predominan di lobus kiri disertai adanya atrofi lobus kiri hepar.

\section{SIMPULAN}

Hepatolitiasis jarang terjadi di Surabaya. Diagnosis lengkap memerlukan kombinasi modalitas pencitraan. Pembedahan tetap menjadi pilihan utama pengobatan definitif. Menurut strategi terapeutik saat ini untuk hepatolitiasis, hepatektomi tampaknya merupakan pengobatan yang paling efektif untuk pasien dengan hepatolitiasis kiri yang terisolasi jika prosedur pembedahan lain tidak dapat mengatasi semua lesi terkait. Perawatan yang baik dapat memberikan luaran yang baik.

\section{DAFTAR PUSTAKA}

1. Vachell HR, Stevens WM. Case of Intrahepatic Calculi. $\mathrm{Br}$ Med $J$. 1906;1:434-46.

2. Nakayama F. Intrahepatic Stones. Dalam: Blumgart LH, penyunting. Surgery of The Liver \& Biliary Tract. Edisi ke-2. London: Churchill Livingstone; 1994. h. 765-74.

3. Lindstrom CG. Frequency of Gallstone Disease in a Well Defined Swedish
Population. Scand J Gastroenterol. 1977;12:341-6.

4. Pitt HA, Venbrux AC, Coleman J, et al. Intrahepatic stones. The transhepatic team approach. Ann Surg. 1994;219:527-37.

5. Harris HW, Kumwenda ZL, SheenChen SM, et al. Recurrent Pyogenic Cholangitis. Am J Surg. 1998;176:347.

6. Jan YY, Chen MF, Wang CS, et al. Surgical treatment of Hepatolithiasis: Long-term results. Surgery. 1996;120:509-14.

7. Kusano $\mathrm{T}$, Isa $\mathrm{T}$, Ohtsubo $\mathrm{M}$, et al. Natural Progression of Untreated Hepatolithiasis. J Clin Gastroenterol. 2001;33:114-17.

8. Rao ARN, Chui AKK. Intrahepatic Stones - an Etiological Quagmire. Indian J Gastroenterol. 2004;23:201-2.

9. Yellin AE, Donovan AJ. Biliary lithiasis and helminthiasis. Am J Surg. 1981;142:128-36.

10. Uchiyama K, Onishi $\mathrm{H}$, Tani $\mathrm{M}$, et al. Indication and Procedure for Treatment of Hepatolithiasis. Arch Surg. 2002;137:149-53.

11. Sheen-Chen SM, Chen WJ, Eng HL, et al. Bacteriology \& Antimicrobial choices in Hepatolithiasis. Am J Infect Control. 2000;28:298-301.

12. Kusano $\mathrm{T}$, Isa $\mathrm{T}$, Ohtsubo $\mathrm{M}$, et al. Natural Progression of Untreated Hepatolithiasis that Shows No Clinical Signs at Its Initial Presentation. J Clin Gastroenterol. 2001;33:114-17.

13. Cheung MT, Wai SH, Kwok PC. Percutaneous Transhepatic Choledoscopic Removal of Intrahepatic Stones. Brit $J$ Sung. 2003;90:1409-15.

14. Kamiya, Kitagawa, Nimura. Intrahepatic Stones. Dalam: Blumgart 
LH, Jarnagin WR, penyunting. Surgery of The Liver, Billiary Tract and Pancreas. Edisi ke-4. Philadelphia: Saunders; 2006. h. 1259-76.

15. Binmoeller KF, Brückner M, Thonke $F$, et al. Treatment of Difficult Bile Duct Stones Using Mechanical, Electrohydraulic and Extracorporeal Shock Wave Lithotripsy. Endoscopy. 1993;25:201-6.

16. Jeng KS, Sheen IS, Yang FS, et al. Precutaneous Transhepatic Placement of Metallic Stents in the Treatment of Complicated Intrahepatic Biliary Stricture With Hepatolithiasis. Am J Gastroenterol. 1999;94:3507-12.

17. Beckingham IJ, Krige JE, Beningfield SJ, et al. Subparietal Hepaticojejunal Access Loop for the Long Term Management of Intrahepatic Stones. $\mathrm{Br}$ J Surg. 1998;85:1360-63.

18. Otani K, Shimizu S, Chijiiwa K, et al. Comparison of Treatments for Hepatolithiasis: Hepatic resection versus Cholangioscopic Lithotomy. $J$ Am Coll Surg. 1999;189:177-82.

19. Fan ST, Choi TK, Lo CM, et al. Treatment of Hepatolithiasis: Improvement of Result by a Systemic Approach. Surgery. 1991;109:474-80. 